\title{
On the Design of a Curriculum that Meets ABET and AIS Requirements: Case of Web Design and Development Program
}

\author{
M. Basel Al Mourad, Member, IACSIT
}

\begin{abstract}
Many academic Information System (IS) institutes are seeking to demonstrate that their curriculum is aligned with professional association guidelines and their programs are accredited by reputable standards. Achieving these two goals is not straightforward. They require thorough understanding to both the curriculum design guidelines as well as the program accreditation criteria. This paper presents a contribution study on the design of curriculum of IS degree with concentration on Web Design and Development. The proposed curriculum demonstrates and follows the principles guiding the IS curriculum design recommended by the Association of Information Systems (AIS) and is aligned with Accreditation Board for Engineering and Technology (ABET) nine program outcome criteria.
\end{abstract}

Index Terms-Curriculum design, ABET accreditation, information systems, web design and development.

\section{INTRODUCTION}

Earning a degree in computing and IS has become one of the popular desired degrees as it can be used widely in all the sectors of the economy [1].

Much of youth future success depends on the educational foundation therefore the quality of the education they receive makes a huge difference. To ensure that an academic program is meeting certain standards necessary to produce graduates who are ready to enter their professions many colleges and institutes have decided to adopt respected curriculum guidelines and opt to support their academic programs with reputable accreditations.

The design of new IS 2010 curriculum [2] recommends short list of core courses that are essential to IS programs, allowing them to customize other IS concentration by creating a list of electives that can serve further needed IS concentrations/tracks that satisfy local job market needs. IS professionals need both an excellent understanding of the domain within which they work and appropriate technology knowledge that satisfy specific organizational role. This can be done by offering a curriculum that does not specify a single career but will provide numerous career tracks. These career tracks will integrate a combination of the core courses and some set of career track electives.

Accreditation is a process by which educational programs or institutions are reviewed to determine if they meet certain standards of quality [3]. The agency started in 1932 as the Engineers' Council for Professional Development (ECPD).

Manuscript received October 9, 2013; revised January 23, 2014.

M. B. Al Mourad is with the Zayed University, P. O. Box 19282, Dubai, UAE (e-mail: basel.almourad@zu.ac.ae)
In 1980 ECPD changed the name to ABET. Today, ABET accredits more than 2,900 programs at more than 600 colleges and universities in USA and worldwide.

ABET accreditation doesn't apply to degrees, departments, colleges, institutions, or individuals but merely academic programs. A program achieves ABET accreditation when it complies with the criteria, policy, and procedures upon which an ABET review is based. In spite of a well-documented process, the ABET accreditation review process typically takes 18 months to complete, starting with a program's formal request for an ABET review [3]. Section II discusses the needs for BSc in Information Systems with concentration in Web Design \& Development (BSc-IS-WDD). Section III presents three factors that are considered in designing the BSc-IS-WDD. Section IV and Section V discuss the BSc-IS-WDD course design philosophy and considerations. Section V briefly introduces program assessment. Finally, Section VI presents the conclusion

\section{Why IS WITH CONCENTRATION IN WEB DESIGN AND DEVELOPMENT CURRICULUM}

The World Wide Web (WWW) revolution without a doubt has changed the way people think, act and most importantly performing a business. After more than two decades, the web still clamps the aptitude of all that is new and what is the next step. Each year, a record number of businesses present their offerings to the WWW. The web has accounted for or influenced $42 \%$ of retail sales in 2009 and by 2014, Forrester research predicted that the web will directly account for $8 \%$ of U.S. retail sales and influence $53 \%$ of consumer purchases [4].

As the number of products and services online grows, web developers will continue to see an increment in job opportunities. The explosion of social media and Web 2.0 sites will require creative thinking coupled with technology-based leadership. This incredible shift in website evolution will contribute to the high demand for skilled and talented web 2.0 developers. It has been reported that the Web development job openings are projected to increase $22 \%$ by 2020 , a rate much faster than average across all industries [5].

With the expected growing demand of web developer, there is an increasing pressure for universities to design and prepare Web Design and Development (WDD) that fully meets the web trends and equips graduates with the theory, knowledge and practical skills to create web solutions that capitalize on the WWW trends.

The IS curriculum requires constant review of new 
technologies, methods and practices, tools, and business applications. Businesses are looking for graduates who know and understand the latest solutions, and master their application to support decision makers at all levels. Systems that can help to solve business problems must be precise, robust, scalable, user-friendly, and adaptable. Information and content management is a key objective within the corporate strategy [6].

\section{PRINCIPLE OF BSC-IS-WWD CURRICULUM DESIGN}

On designing the BSc-IS-WWD program curriculum we considered three main factors Fig. 1. The first factor considers understanding stakeholder requirements. This is done by exploring www.w3.org and carrying out informal meetings with specific IT directors, IT project Manager and web developer experts, and reviewing the needs of those industry experts and hiring agencies. The second factor considers ACM (the Association for Computing Machinery) and AIS (the Association for Information Systems) curriculum guidelines for undergraduate degree programs in Information Systems (IS) that for the first time include both core and elective courses suited to specific career tracks [2]. The third factor considers ABET Criteria for Accrediting Computing Programs [3]. Below is a detailed explanation for each of these factors.

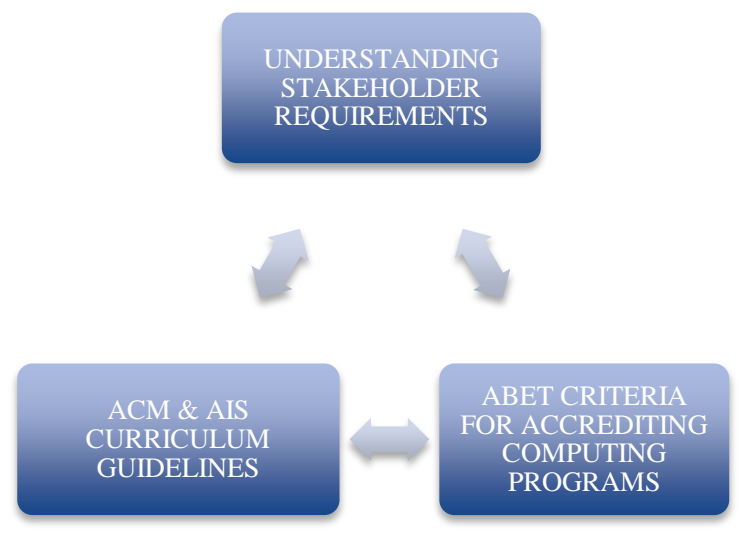

Fig. 1. Principle of BSc-IS-WWD curriculum design.

\section{A. Understanding Stakeholder Requirements}

Curriculum contents design in many higher education institutes considers only the educational vision of the faculty experts, and expects a successful output related with what they appreciate as the employer's needs. It is vital for graduates to enrich their knowledge and proficiency with technical and non-technical [7], [8]. Recent studies showed that the design of any program or concentration curriculum should be derived from correlation of academic and industry requirements (i.e. stakeholder) [9], [10]. Stakeholder theory has been advanced and justified in management literature on the basis of its descriptive accuracy, instrumental power, and normative validity. Stakeholder thoery is intended both to explain and guide the structure and operation of an established corporation where it is viewed as an organisational entity through which numerous and diverse participants accomplish multiple, though not always entirely consistent, purposes [11]. In its application to highereducation, stakeholder analysis focuses on how to define quality in education and serve the needs of its constituents. This entails building consensus between stakeholders in the educational process, Stakeholders include students, faculty, industry, and the community [12].

After consulting the stakeholder (Faculties, Web Administrators, Students and Alumni) and understanding their requirements the BSc-IS-WDD introduces the courses presented in Table I, as part of the WDD specialization requirements (The courses will be considered as elective courses in ACM and AIS curriculum guidelines terminologies). Each course is three credit hours.

TABLE I: BSC-IS WWDC COURSE SPECIALIZATION REQUIREMENTS
\begin{tabular}{|l|l|}
\hline \multicolumn{2}{|c|}{ SPECIALIZATION REQUIREMENTS (15 CR. HRS) } \\
\hline \multicolumn{1}{|c|}{ COURSE TITLE } & \multicolumn{1}{c|}{ COURSE PRE-REQUISITE } \\
\hline Web Animation & O.O. Programming \\
\hline Multimedia Technology & O.O. Programming \\
\hline $\begin{array}{l}\text { Enterprise Web } \\
\text { application }\end{array}$ & $\begin{array}{l}\text { Web Design and Development } \\
\text { OO Programming }\end{array}$ \\
\hline $\begin{array}{l}\text { Web Databases } \\
\text { Database Management Systems } \\
\text { Web Design and Development }\end{array}$ \\
\hline $\begin{array}{l}\text { Web Services \& Service } \\
\text { Oriented Architecture }\end{array}$ & Web Design and Development \\
\hline
\end{tabular}

\section{B. ACM \& AIS Curriculum Guidelines}

BSc-IS-WDD curriculum comes under the umbrella of AIS curriculum design which are stated in the latest IS 2010 curriculum publication [2]. The publication stated nine key principles. The two keys that are related to curriculum content are described as follows:

- The model curriculum has a core of content that is common to all information systems programs

- The model curriculum has career targets that require both core and elective courses.

We considered the two keys by including a set of core courses and set of concentration (elective) courses. Fig. 2 shows the BSc-IS-WDD core and concentration courses

\section{Abet Criteria for Accrediting Computing Programs}

Several available curriculum models provide guidelines for adoption and further shaping the curriculum of undergraduate programs [13]-[15]. To support the ABET accredited program efforts were made to make sure that BSc-IS-WDD program is aligned with ABET nine criteria [3]. ABET has five criteria statements about objectives and assessments. Criterion $2 \& 3$ are related to Program Educational Objectives and Program outcomes respectively:

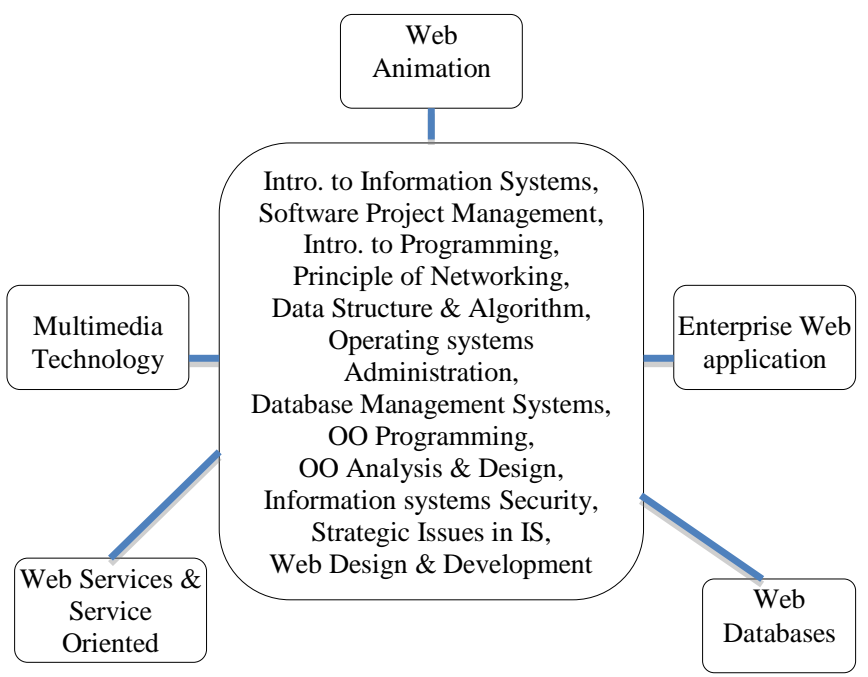

Fig. 2. Name of core and concentration courses. 
- Criterion 2. The program has documented measurable educational objectives that are based on the needs of program requirements.

- Criterion 3. The program has documented measurable outcomes that are based on the needs of the program's constituencies.

The Program Educational Objectives and Program Outcomes of BSc-IS-WDD are defined below.

BSc-IS-WDD Objectives: The IS program with concentration in WDD is designed to prepare graduates who are able to:

1) Demonstrate knowledge of principles and advanced concepts in Web-based Information Systems analysis, design and implementation.

2) Understand and analyze the important issues with regard to the social impact of advanced and emerging computer information technologies

3) Apply Computing and Information Systems concepts and use software tools to design and develop standards-compliant web-based applications.

4) Formulate questions and critically investigate and solve business-related computing \& information systems problems

5) Be engaged in ethical issues in information systems, particularly questions of social responsibility and professional decision-making

6) Build and lead team of professionals to tackle challenging Computing \& Information Systems Projects

7) Communicate effectively and professionally with technical and non-technical professionals.

BSc-IS-WDD Outcomes: Upon graduation, each IS graduate will possess the knowledge, skills, and ability to:

1) Apply knowledge of computing, information systems and mathematics.

2) Analyze a business problem, identify \& define the requirements appropriate for web design $\&$ development

3) Design, implement and evaluate a computer-based system, process, component, or program to meet desired needs.

4) Function effectively in teams to create a project plan to accomplish a common goal.

5) Understand professional, ethical and social responsibilities.

6) Communicate effectively with a range of audiences.

7) Analyze the impact of computing on individuals, organizations and society, including ethical, legal, security and global policy issues.

8) Design, develop, and implement cutting-edge websites that blend interactive media with service-oriented architectures.

9) Create end-to-end Web solutions for e-business and demonstrate how these can support IS strategies, and business process innovation

Each course in BSc-IS-WDD program is mapped with the corresponding program-level outcome. This mapping is presented in Table II. Empty cells refer to the fact he the elective course doesn't cover certain outcomes (the outcomes are covered by the core courses). Program core course mapping with the program level outcome is presented in Table IV in the appendix. The mapping provides an effective framework to use course-level assessment results as a tool to assess the extent to which the Program objectives/outcomes are being met.

TABLE II: BSC-IS-WDD PROGRAM COURSE MAPPING WITH PROGRAM LEVEL OUTCOME

\begin{tabular}{|c|c|c|c|c|c|c|c|c|c|}
\hline \multirow{2}{*}{$\begin{array}{c}\text { WPDD } \\
\text { CPIALIZATION } \\
\text { COURSES }\end{array}$} & \multicolumn{7}{|c|}{ PROGRAM OUTCOMES (PO) } \\
\cline { 2 - 9 } & $\mathrm{A}$ & $\mathrm{B}$ & $\mathrm{C}$ & $\mathrm{D}$ & $\mathrm{E}$ & $\mathrm{F}$ & $\mathrm{G}$ & $\mathrm{H}$ & $\mathrm{I}$ \\
\hline WEB ANIMATION & & $\mathrm{X}$ & $\mathrm{X}$ & & & & & $\mathrm{X}$ & $\mathrm{X}$ \\
\hline $\begin{array}{c}\text { MULTIMEDIA } \\
\text { TECHNOLOGY }\end{array}$ & $\mathrm{X}$ & $\mathrm{X}$ & $\mathrm{X}$ & & & & & $\mathrm{X}$ & $\mathrm{X}$ \\
\hline $\begin{array}{c}\text { ENTERPRISE WEB } \\
\text { APPLICATION }\end{array}$ & & $\mathrm{X}$ & $\mathrm{X}$ & & & & & $\mathrm{X}$ & $\mathrm{X}$ \\
\hline WEB DATABASES & & & $\mathrm{X}$ & & & & & $\mathrm{X}$ & $\mathrm{X}$ \\
\hline $\begin{array}{c}\text { WEB SERVICES \& } \\
\text { SERVICE ORIENTED } \\
\text { ARCHITECTURE }\end{array}$ & & & $\mathrm{X}$ & & & & & $\mathrm{X}$ & $\mathrm{X}$ \\
\hline
\end{tabular}

\section{WDD CONCENTRATION COURSE DESIGN PHILOSOPHY}

The ABET standards require that students must have at least 30 credit hours of study in information systems topics, at least 15 credit hours of study in an information system environment, such as business, at least 9 credit hours of study in quantitative analysis, and at least 30 credit hours of study in general education. The information systems area is further divided into core and advanced content. According to ABET the advanced content should be at least 12 credit hours and that build on the IS core to provide a depth of knowledge.

The normal BSc in Information Systems degree consists of 41 courses, an internship and an applied research project. Each course is equivalent to three credit hours. The full program requires 129 credit hours for the degree of BSc with concentration in WDD as shown in Table III.

TABLE III: CURRICULUM FOR BSC- IN IS - CONCENTRATION WDD

\begin{tabular}{|c|c|c|c|}
\hline CATEGORY REQUIREMENTS & $\begin{array}{c}\text { GENERAL } \\
\text { REQUIREMENT }\end{array}$ & IS & TOTAL \\
\hline General Education & 27 & & 27 \\
\hline Humanities \& Social Sciences & 6 & & 6 \\
\hline Natural \& Applied Sciences & 6 & 33 \\
\hline $\begin{array}{c}\text { Business Requirements for IT } \\
\text { professionals }\end{array}$ & 33 & 42 & 42 \\
\hline $\begin{array}{c}\text { Core Requirements } \\
\text { WDD Concentration } \\
\text { Requirements }\end{array}$ & & 15 & 15 \\
\hline TOTAL & $\mathbf{7 2}$ & $\mathbf{5 7}$ & $\mathbf{1 2 9}$ \\
\hline
\end{tabular}

The course design philosophy for the WDD concentration was based on the following key design criteria:

1) The requirements of the Web Design and Development profession

2) The coherence among the concentration courses and the trimming down of potential overlaps.

3) The appropriateness of the courses' content in both depth and breadth

4) THE appropriateness of courses' objectives and learning outcomes in terms putting more focus on developing higher-order cognitive skills (analysis, synthesis, application) and a good balance between theory and practice.

5) The appropriateness of the support (pre-requisite) core courses. Reference made to other WDD concentration programs being offered in other European and NA universities 


\section{COURSE DESIGN CONSIDERATIONS}

The following section summarizes the design criteria that have been used to in the selection of the WDD concentration specific courses and their learning outcomes.

\section{A. Web Animation}

This course covers animation techniques used in the creation of web pages. Students will use a current animation tool for webpage design and animation technique. The proposal of this course is driven by the need of the e-commerce and marketing sector, for professionals who are able to create dynamic, well-structured and attractive websites (criteria 1). This course does not aim essentially to teach animation concepts in their generality but rather to illustrate the application of these concepts via typical animation software. The course is organized into four parts. In the first part, the students will be exposed to the general description of animation concepts. In the second part they will master the fundaments of typical web animation development software. The third and the fourth part will cover the two core animation modules, namely content animation and interaction.

\section{B. Multimedia Technology}

This course is oriented towards the web content side, focusing on the multimedia nature characterizing today's websites. This course aims to provide essential practical knowledge of the elements that compose the multimedia information, namely, text, audio, video and graphic. This will permit students to gain a better understanding of the requirements and issues related to the upper layer of webpage authoring development, e.g. web animation. From this prospect, it is aligned with criteria 1 . This course provides opportunities for the students to pursue more specialized disciplines, such as image processing, graphics and animation. The course covers theoretical and practical aspects of digital media whereby students will learn the fundamentals of data digitization and the physical and logical structure of the multimedia data. The course covers also data compression techniques, exposing students to the fundamental compression paradigms, namely, the entropy, the source, and the hybrid techniques. The last part of the course will be dedicated to a typical web-oriented virtual reality modeling language. This topic will allow the students to design on-line virtual worlds by integrating a variety of multimedia components.

\section{Enterprise Web Applications}

This course is introduced to prepare students to become profession in multi-tier-based web applications using Java technology. Such skills are greatly demanded in the e-sectors that characterize the business landscape (criteria 1). In this course, students will get exposure to the Enterprise Application Architecture and will acquire the necessary knowledge of load balancing in network infrastructure design in a multitier-based web applications context. The second core module of this course (Web application design) is intended to address the Program Concentration Outcomes B: "Analyze a business problem, identify and define the requirements appropriate for web design and development". Through the techniques and tools provided in this module, students will learn how to design enterprise web application solutions to address a given problem. In the third module, students will be taught the fundamental aspects of advanced topics in Web-services.

\section{Web Service and Service Oriented Architecture}

This course aims to provide the students with an immense knowledge of the next generation of web-based technology. From this prospect it is a complement to the Enterprise Web Development course (design criteria 2). This course exposes the students to Web Services concepts and the associated standard protocols such as SOAP, WSDL and UDDI, along with their applications and implications in the context of Service-Oriented Architecture. Through this course the students will acquire the skill of web application development using Service-Oriented Development methodologies.

\section{E. Web Databases}

This course aims to strengthen students' knowledge and background in database management within a web application context. This course will build on student's prior knowledge of web development and database management to equip them with skills and capabilities for developing client/server-side applications focusing on database interface design. In this course, students are expected to master the PHP programming language, the database-oriented language MySQL, and to acquire the skill of blending these tools for the purpose of creating dynamic web database interfaces.

\section{PROGRAM EVALUATION}

To evaluate the design of the program and the program learning outcomes. We use the assessment grades in every course to evaluate whether the course is meeting the course learning outcomes. An Excel sheet for every course is used for this purpose where every question grad for every student in the evaluated assessment is entered and mapped to the corresponding learning outcomes of the course being assessed.

The aggregation outcome of these sheets is cascaded to evaluate the whole program. A threshold is used as benchmark for every course and eventually for the whole program. More detail about the evaluation will appear in future paper.

\section{CONCLUSION}

Given the usefulness of the WDD profession and the various associated roles (i.e. Web Developer, Web Administrator) we have blended a coherent set of five WDD concentration-specific courses, which together contribute towards achieving the concentration objectives. In doing, careful design planning has been undertaken to ensure:

- More focus on applications and higher-level cognitive skills

- Thorough coverage of important topics that are deemed very relevant to the WDD profession.

By exposing students to concepts and applications pertaining to web animation, multimedia technology, enterprise web application, web services and service oriented and web database and by providing the suitable background in information systems and web design and development and 
Database management systems, we believe that the Bachelor of CIS with concentration in WDD is very well positioned to serve the educational needs of future WDD professionals.

\section{APPENDIX}

TABLE IV: PROGRAM CoRe COURSE MAPPING With THE PROGRAM LeVEL OUTCOME

\begin{tabular}{|c|c|c|c|c|c|c|c|c|c|c|}
\hline \multicolumn{11}{|c|}{ PROGRAM OUTCOMES (PO) } \\
\hline & CORE COURSES & $\mathrm{A}$ & B & $\mathrm{C}$ & D & $\mathrm{E}$ & $\mathrm{F}$ & $\mathrm{G}$ & $\mathrm{H}$ & I \\
\hline $\begin{array}{l}\text { ITGN } \\
215\end{array}$ & $\begin{array}{l}\text { Introduction to } \\
\text { Information Systems }\end{array}$ & $\mathrm{X}$ & & $\mathrm{X}$ & & & & $\mathrm{X}$ & & \\
\hline $\begin{array}{l}\text { BBU } \\
\text { S 230 }\end{array}$ & $\begin{array}{l}\text { Software Project } \\
\text { Management }\end{array}$ & & & & $\mathrm{X}$ & $\mathrm{X}$ & $\mathrm{X}$ & & $\mathrm{X}$ & \\
\hline $\begin{array}{l}\text { ITGN } \\
230\end{array}$ & $\begin{array}{l}\text { Introduction to } \\
\text { Programming }\end{array}$ & $\mathrm{X}$ & & $\mathrm{X}$ & & & & & $\mathrm{X}$ & \\
\hline $\begin{array}{l}\text { ITGN } \\
235\end{array}$ & $\begin{array}{l}\text { Principles of } \\
\text { Networking }\end{array}$ & $\mathrm{X}$ & $\mathrm{X}$ & & $\mathrm{X}$ & & & & $\mathrm{X}$ & $\mathrm{X}$ \\
\hline $\begin{array}{l}\text { ITGN } \\
240\end{array}$ & $\begin{array}{l}\text { Data Structures \& } \\
\text { Algorithms }\end{array}$ & $\mathrm{X}$ & & $\mathrm{X}$ & & & & & $\mathrm{X}$ & \\
\hline $\begin{array}{l}\text { ITGN } \\
245\end{array}$ & $\begin{array}{l}\text { Operating Systems } \\
\text { Administration }\end{array}$ & & & & $\mathrm{X}$ & & & & & $\mathrm{X}$ \\
\hline $\begin{array}{l}\text { ITGN } \\
250\end{array}$ & $\begin{array}{l}\text { Database Management } \\
\text { Systems }\end{array}$ & & $\mathrm{X}$ & $\mathrm{X}$ & & & & & $\mathrm{X}$ & \\
\hline $\begin{array}{l}\text { TGN } \\
315\end{array}$ & $\begin{array}{l}\text { Object-Oriented } \\
\text { Programming }\end{array}$ & $\mathrm{X}$ & & $\mathrm{X}$ & & & & & $\mathrm{X}$ & \\
\hline $\begin{array}{l}\text { ITIS } \\
421 \\
\end{array}$ & $\begin{array}{l}\text { Object Oriented } \\
\text { Analysis \& Design }\end{array}$ & & $\mathrm{X}$ & $\mathrm{X}$ & & & & & & \\
\hline $\begin{array}{l}\text { ITGN } \\
345 \\
\end{array}$ & $\begin{array}{l}\text { Information Systems } \\
\text { Security }\end{array}$ & $\mathrm{x}$ & & & & & & $\mathrm{X}$ & $\mathrm{X}$ & \\
\hline $\begin{array}{l}\text { TIS } \\
414\end{array}$ & Strategic Issues in IS & $\mathrm{X}$ & $\mathrm{X}$ & & & $\mathrm{X}$ & & $\mathrm{X}$ & & $\mathrm{X}$ \\
\hline $\begin{array}{l}\text { ITGN } \\
405\end{array}$ & Internship & & $\mathrm{X}$ & & $\mathrm{X}$ & $\mathrm{X}$ & & $\mathrm{X}$ & & \\
\hline $\begin{array}{l}\text { T IS } \\
440\end{array}$ & Capstone Project & $\mathrm{X}$ & $\mathrm{X}$ & $\mathrm{X}$ & $\mathrm{X}$ & $\mathrm{X}$ & $\mathrm{X}$ & $\mathrm{X}$ & $\mathrm{X}$ & $\mathrm{X}$ \\
\hline $\begin{array}{l}\text { ITGN } \\
350\end{array}$ & $\begin{array}{l}\text { Web Design \& } \\
\text { Development }\end{array}$ & $\mathrm{X}$ & $\mathrm{X}$ & & & & & & $\mathrm{X}$ & $\mathrm{X}$ \\
\hline
\end{tabular}

\section{ACKNOWLEDGMENT}

This study has been achieved while I was working in the University of Dubai (UD), UAE. The support of UD faculty is highly appreciated.

\section{REFERENCES}

[1] Digest of Education Statistics, U.S. Department of Education, 2012.

[2] H. Topi, J. Valacich, R. Wright, K. Kaiser, J. Nunamaker, and J. Sipior, et al. IS 2010: Curriculum Guidelines for Undergraduate Degree Programs. Association for Computing Machinery and Association for Information Systems, 2010
[3] ABET. (2010). Criteria for accrediting computing programs. [Online]. Available:

http://www.abet.org/uploadedFiles/Accreditation/Accreditation_Proce ss/Accreditation Documents/Current/abet-cac-criteria-2011-2012.pdf

[4] Z. Stambor. (2010). E-retail will influence 53\% of purchases by 2014 forrester says. Internet Retailer. [Online]. Available: http://www.internetretailer.com/2010/03/08/e-retail-will-influence-53 -of-purchases-by-2014-forrester-says

[5] D. Greenspan. (2012, May 29). Best computer jobs for the future. IT Career News. [Online]. Available: http://www.itcareerfinder.com/brain-food/blog/entry/best-computer-jo bs-for-the-future.html

[6] J. Fustos and A. Moreno, "Computing curricula disputes: how accreditation documents and curriculum guidelines might help,' Information Resources Management Association, 2005.

[7] L. B. Smith, C. S.Hunt, R. Berry, and D. Hunt, "An integrated IT curriculum model for advancing education in information technologies, learning and performance," Information Technology, Learning \& Performance Journal, vol. 23, no. 1, pp. 7-19, 2005.

[8] J. G. Calhoun, E. T. Vincent, G. L. Calhoun, and L. E. Brandsen, "Why competencies in graduate health management and policy education?" The Journal of Health Administration Education, vol. 251, pp. 17-35, 2005.

[9] S. Srinivasan, J. Guan, and A. L.Wright, "A new CIS curriculum design approach for the 21st centuary," Journal of Computer Information Systems, vol. 39, no. 3, pp. 99-106, Apr. 1999.

[10] T. N. Janicki, T. L. Lenox, R. Logan, and C. R. Woratschek, "Information systems/technology employer needs survey," Information Systems Education, vol. 6, no. 18, 2008.

[11] T. Donaldson, "The stakeholder theory of the corporation: concepts, evidence, and implications," Academy of Management Review, 1995.

[12] C. Hill, "Stakeholder-agency theory," Journal of Management Studies, vol. 29, pp. 131-154, 1992.

[13] A. Tatnall et al., "Evolution of information systems curriculum in an Australian university over the last twenty-five years," In Education and Technology for a Better World, A. Tatnall and A. Jones Ed. Springer Berlin Heidelberg, 2009, pp. 238-246.

[14] T. Dodson, "Curriculum decisions: assessing and updating IS curriculum," in Proc. the Fourteen Americas Conference on Information Systems, 2008, p. 124.

[15] M. B. A. Mourad, "The curriculum design of computing \& information systems with concentration in database systems," presented at the $5^{\text {th }}$ International Conference Information Systems, Berlin, Germany, 2012.

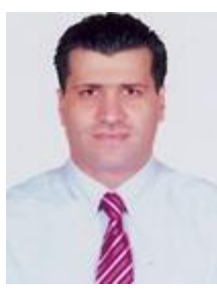

M. B. Al Mourad has received his BSc in informatics engineering from Aleppo University, Syria, and his $\mathrm{PhD}$ degree in computer science from Cardiff University of Wales, United Kingdom. He has served in various International Universities. He is currently an assistant professor in Zayed University, Dubai, UAE Dr. Al-Mourad is active in several research areas where he published numerous articles including: IT service management, heterogeneous data management, semantic web, web accessibility and community of practice. 